\title{
Self-skincare knowledge and practice described by elderly persons in the mid-west of Minas Gerais
}

\section{Abstract}

The present study aimed to assess the knowledge and practices reported by the elderly in relation to basic care of one's skin. A cross sectional study was performed from November 2011 to August 2012 in Arcos, Minas Gerais, based on a structured questionnaire administered to 250 elderly persons, with answers statistically analyzed. Knowledge and practices of self-skincare were evaluated from the median number of ten questions answered by the elderly. Most of the sample population were women (54.8\%), aged between 60 and 69 years $(52.4 \%$ ), with a primary education $(71.6 \%)$ and working in a job where they were exposed to direct sunlight (58.0\%). The majority $(76.4 \%)$ said they did not use protective sun filter despite considering it important $(77.6 \%)$. The use of body

Key word: Elderly; Skin; Nursing; Self Care. moisturizing creams was reported by $55.6 \%$. An association $(p<0.05)$ was identified between the variables practice/knowledge and gender and practice outdoor activity. Further studies can be conducted as a result of the present research to clarify factors related to non-adherence to self-skincare, and educational measures should be put in place for the entire population, regardless of age, to prevent pathological skin aging.

Juliana Ladeira Garbaccio

Amanda Domingos Ferreira ${ }^{1}$ Amanda Laís Gonçalves Gama Pereira' 


\section{INTRODUCTION}

The aging process varies from person to person and between different human biological systems. The skin is an organ that is used to identify age on a daily basis. As it is an external, exposed organ, it is subject to environmental damage, especially that caused by ultraviolet (UV) rays. Consequently, the use of sunscreen has become necessary. ${ }^{1}$

The skin of adults goes through several profound transformations as the age of an individual advances. The following physiological alterations to the cutaneous tissue occur: greater cutaneous fragility; a weaker barrier against external factors; insufficient thermoregulation to deal with heat, caused by the decrease in the number of sweat glands; rough, dry skin, caused by the reduction in the number of sebaceous glands, which leads to low oil production; less sensitive stimulation; a decrease in elasticity; flabbiness; alterations to the immunological cellular response and a thinner dermis and epidermis. These modifications make the skin of the elderly individual more vulnerable to external factors. ${ }^{2}$

From a dermatological point of view, skin aging is caused by two distinct phenomena (intrinsic and extrinsic). The intrinsic phenomenon is related to the chronological and genetic effects on the skin and adjacent tissues, which become dehydrated, rough and flabby. The extrinsic phenomenon is linked to lifestyle habits and environmental factors. Photoaging is correlated with chronic exposure to the sun's rays, leading to several types of senile alterations, as well as the susceptibility of the individual to benign or malignant neoplasia. ${ }^{3}$

Most studies of the skin of elderly individuals deal with adherence to the use of sunscreen, ${ }^{4}$ the development of ulcers in intensive care units (ICU), ${ }^{5}$ nursing diagnoses of the skin, ${ }^{6}$ ultraviolet and carcinogenic radiation, ${ }^{7}$ skin modifications in the elderly, versus photoaging, ${ }^{8}$ sunscreens, ${ }^{9}$ the aging process and assistance for the elderly, ${ }^{10}$ and the study of age-related modifications to human skin using histomorphometry and autofluorescence. ${ }^{11}$

Considering the abovementioned phenomena, as well as the potential neglect of the skin by elderly individuals during their lives, this section of the population is more at risk of developing lesions and soft tissue diseases. This leads to the following questions: what techniques do the elderly use to protect their skin and how much knowledge about skin protection do they have? Is there a correlation between their sociodemographic characteristics, practices and knowledge in relation to skin care?

Therefore, the aim of the present study was to assess the knowledge and practices of elderly individuals in relation to basic skin care.

\section{METHODS}

This cross-sectional study was conducted between November 2011 and August 2012 in the Brazilian town of Arcos, in the state of Minas Gerais, which has a population of approximately 36,597 inhabitants. Arcos is located $230 \mathrm{~km}$ from the city of Belo Horizonte. ${ }^{12}$

The study population involved elderly residents in the municipality who were registered with the town's Unidades de Atenção Primária à Saúde (Primary Healthcare Units) (UAPS) and/ or Programa Saúde da Família (Family Health Program) (PSF).

Of the seven UAPS in the area, two were included in the present study due to the high numbers of elderly individuals registered therein: Brasília de Arcos (396); and Zona Norte de Arcos (333). Thus, the total sample size was 729 individuals. Based on this number, the sample was calculated per UAPS, considering a standard 
deviation of 0.05 and a confidence interval of $95 \%$. The result was 250 elderly individuals, who were selected at random from the register.

The following inclusion criteria were defined for the present study: participants must be at least 60 years of age; they must have no diagnosed or suspected cognitive deficits (established during interviews); they must be registered with one of the two abovementioned UAPS. The exclusion criteria were as follows: individuals with any diagnosis or suspicion of a cognitive deficit; individuals registered with one of the UAPS that were not included in the present study.

The elderly individuals were approached in their homes or workplaces and verbally invited to participate in the research. The data was collected using a structured questionnaire, created specifically for the present study, containing 25 questions relating to: I. sociodemographic data; II. Practices and knowledge of the elderly in relation to their skin care. The questionnaire was applied in person and individually with each elderly participant. The three interviewers were nursing students who had been previously trained in the procedure. The aim and method of the research was explained to each elderly individual and if they agreed to participate, they were asked to sign a Free and Informed Consent Form (FICF).

After the data collection, the results were tabulated using Microsoft Office Excel 2007 and then analyzed (descriptively and statistically) using version 17.0 of the Statistical Package for the Social Sciences (SPSS). The chi-squared test and Fisher's Exact test were also applied.

Of the total of 25 questions, 10 (eight referring to practices and two referring to knowledge) were used to calculate the median of correct answers of the elderly participants: Do you use sunscreen?; Do you use sunscreen on cloudy days?; Do you use body moisturizer?;
How often do you use body moisturizer?; Have you ever used a bomemade suntan lotion?; What is the temperature of the water when you take a bath/shower?; Do you use a loofah on your skin?; How much liquid do you ingest on a daily basis?; Do you think it is important to use sunscreen?; Do you know the number of sunscreen factors? The other questions were only assessed descriptively and were not included in the calculation, as they were considered more specific and the elderly individuals would require guidance from health professionals, particularly gerontologists and geriatric nurses, when answering them.

The present study received approval from the Research Ethics Committee of the Pontifícia Universidade Católica de Minas (the Catholic University of Minas Gerais) under protocol number CAAE 0277.0.213.000-11, as per Resolution 196/96 of the Conselho Nacional de Saúde (National Health Council). ${ }^{13}$

\section{RESULTS}

In total, 319 individuals were registered with a UAPS. Of these, 50 were not found at home, and 19 exhibited a cognitive deficit (identified in UBS records) and were excluded from the study.

Subsequently, of the final sample of 250 elderly individuals, 245 (98\%) individuals were approached in their homes and five others (2\%) were approached in their place of work.

The following prevalence rates were recorded for this sample: women ( $\mathrm{n}=137 ; 54.8 \%)$; aged between 60 and 69 years (52.4\%); 119 (47.6\%) defined their ethnicity as Caucasian; 179 (71.6\%) stated that they had completed primary education; 141 (56.4\%) were married; $150(60.0 \%)$ had spent most of their lives in an urban area and 164 (58.0\%) worked in jobs that entailed direct exposure to sunlight. ${ }^{14}$ (Table 1). 
Table 1. Sociodemographic profile of elderly individuals registered in the Primary Healthcare Unit ( $\mathrm{n}=250)$. Arcos. MG. 2011-2012.

\begin{tabular}{llcc}
\hline & \multicolumn{1}{c}{ Variables } & $\mathrm{n}$ & $\%$ \\
\hline Gender & & & \\
& Female & 137 & 54.8 \\
& Male & 113 & 45.2 \\
Age & & & \\
& 60 to 69 & 131 & 52.4 \\
& 70 to 79 & 91 & 36.4 \\
& $\geq 80$ & 28 & 11.2
\end{tabular}

Ethnicity

$\begin{array}{lcc}\text { Caucasian } & 119 & 47.6 \\ \text { Afro-Brazilian } & 31 & 12.4 \\ \text { Mixed-Race } & 12 & 4.8 \\ \text { Other } & 88 & 35.2\end{array}$

Education

$\begin{array}{lcc}\text { Illiterate } & 50 & 20.0 \\ \text { 1st to 4th grade } & 179 & 71.6 \\ \text { Primary education } & 12 & 4.8 \\ \text { High school/third level course } & 9 & 3.6\end{array}$

Marital status

$\begin{array}{lcc}\text { Married/ Stable union } & 141 & 56.4 \\ \text { Widow } & 72 & 28.8 \\ \text { Single } & 23 & 9.2 \\ \text { Divorced } & 14 & 5.6\end{array}$

Residence

Urban area 150

60.0

Rural area

$100 \quad 40.0$

Profession*

Agricultural workers $\quad 5923.6$

$\begin{array}{lll}\text { Unemployed (housework) ** } & 57 & 22.8\end{array}$

$\begin{array}{lll}\text { General domestic services } & 48 & 19.2\end{array}$

Extractive industry and civil construction $\quad 29 \quad 11.6$

Mechanic/maintenance of machines and $\quad 19 \quad 7.6$

equipment

$\begin{array}{lll}\text { Vendors and commercial services } & 18 & 7.2\end{array}$ 


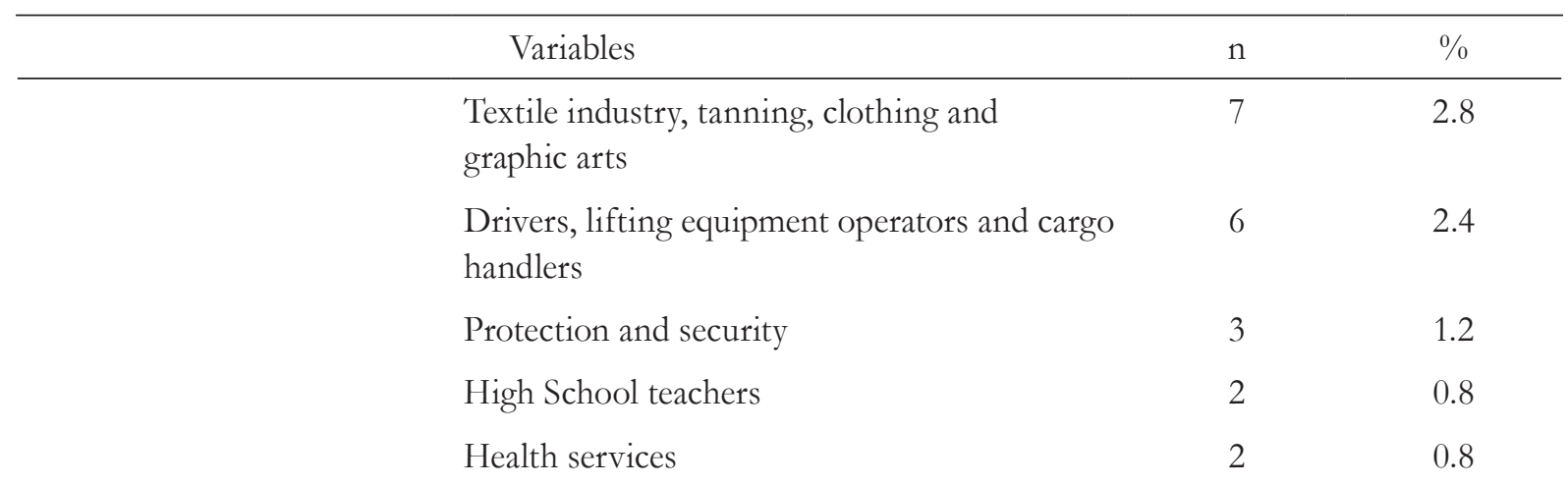

Occupational exposure

to the sun

$\begin{array}{lll}\text { No } & 104 & 41.6 \\ \text { Yes } & 146 & 58.4\end{array}$

Performs outdoor activities

$\begin{array}{lll}\text { No } & 137 & 54.8 \\ \text { Yes } & 113 & 45.2\end{array}$

*Categorization of professions performed based on data from the Brazilian Occupations Classification (CBO). 2010; **CBO 2010 does not categorize people who work "in the home" so they were included in the unemployed section. ${ }^{14}$

Table 2 displays the data related to the practices and knowledge of the elderly participants in terms of looking after their own skin. In total, 191 (76.4\%) confirmed that they did not use sunscreen; 194 $(77.6 \%)$ thought it was important to use this type of product; $223(89.2 \%)$ did not use sunscreen on cloudy days and three $(1.2 \%)$ had used homemade suntan lotion. The use of body moisturizing creams was cited by 139 (55.6\%), of whom 77 (55.4\%) used such products on a daily basis.

Table 2. Practices and knowledge of elderly individuals in relation to skin care ( $\mathrm{n}=250$ ). Arcos. MG. 2011-2012.

\begin{tabular}{lcc}
\hline \multicolumn{1}{c}{ Variables } & $\mathrm{n}$ & $\%$ \\
\hline $\begin{array}{l}\text { Practices reported } \\
\text { Uses sunscreen }\end{array}$ & & \\
No & 191 & 76.4 \\
Sometimes & 36 & 14.4 \\
Daily & 23 & 9.2 \\
Uses sunscreen on cloudy days & & \\
No & 223 & 89.2 \\
Yes & 23 & 9.2 \\
Sometimes & 4 & 1.6
\end{tabular}




\begin{tabular}{|c|c|c|}
\hline Variables & $\mathrm{n}$ & $\%$ \\
\hline \multicolumn{3}{|c|}{ Uses/has used homemade suntan lotion } \\
\hline No & 247 & 98.8 \\
\hline Yes & 3 & 1.2 \\
\hline \multicolumn{3}{|l|}{ Uses body moisturizer } \\
\hline No & 111 & 44.4 \\
\hline Yes & 139 & 55.6 \\
\hline \multicolumn{3}{|c|}{ Frequency of use of body moisturizer } \\
\hline Daily & 77 & 30.8 \\
\hline No criteria & 62 & 24.8 \\
\hline Never & 111 & 44.4 \\
\hline \multicolumn{3}{|l|}{ Temperature of bathwater } \\
\hline Warm & 196 & 78.4 \\
\hline Cold & 40 & 16.0 \\
\hline Hot & 14 & 5.6 \\
\hline \multicolumn{3}{|c|}{ Uses a loofah when bathing } \\
\hline Daily & 153 & 61.2 \\
\hline Never & 69 & 27.6 \\
\hline Rarely & 28 & 11.2 \\
\hline \multicolumn{3}{|c|}{ Liquids ingested/day (approx.) } \\
\hline 1 liter & 129 & 51.6 \\
\hline$\geq 2$ liters & 121 & 48.4 \\
\hline \multicolumn{3}{|l|}{ Knowledge } \\
\hline \multicolumn{3}{|c|}{ Importance of using sunscreen } \\
\hline No & 56 & 22.4 \\
\hline Yes & 194 & 77.6 \\
\hline \multicolumn{3}{|l|}{ SPF numbers } \\
\hline No & 84 & 33.6 \\
\hline Yes & 166 & 66.4 \\
\hline
\end{tabular}

$\mathrm{SPF}=$ sun protection factor

In total, $249(99.6 \%)$ of the participants said that they took a shower every day, with 196 (78.4\%) using warm water and 153 (61.2\%) using a loofah.
With regard to water ingestion, $129(51.6 \%)$ of the participants consumed an approximate quantity of one liter per day. 
Table 3. Distribution of the sociodemographic variables in relation to the practices and knowledge of skin care among elderly individuals $(\mathrm{n}=250)$, categorized by the median of success in the questions. Arcos. MG. 2011-2012.

\begin{tabular}{lcccc}
\hline & Variables & $\mathrm{n}$ & \multicolumn{3}{c}{$\begin{array}{c}\text { Reported practices and knowledge } \\
\text { (Success in the questions } \geq 50 \% \text { ) }\end{array}$} \\
\cline { 3 - 5 } & & $\mathrm{n}$ & $\%$ & p-value* \\
\hline Gender & 137 & 88 & 64.2 & $\mathbf{0 . 0 1}$ \\
$\quad$ Female & 113 & 56 & 49.6 & \\
Male & & & & \\
Practice of open air activities & 137 & 72 & 52.5 & $\mathbf{0 . 0 4}$ \\
No & 113 & 72 & 63.7 & \\
Yes & & & & \\
\hline
\end{tabular}

*Fisher's Exact Test.

Table 3 displays the results of the bivariate analysis between the sociodemographic variables and the variables for skin care practices and knowledge. The data considered the percentage of correct answers in the questions (defined by the median). A statistically significant correlation $(p<0.05)$ was found between the variables practices/knowledge, gender and the performance of outdoor activities.

Female elderly individuals (64.2\%) who practiced some form of outdoor activity $(63.7 \%)$ exhibited the most appropriate practices and knowledge in relation to skin care. No statistically significant correlations $(p>0.05)$ were found for the remaining variables and as such, they were not included in Table 3.

The answers to the questions not used in the calculation of the median were also assessed. The majority ( $\mathrm{n}=147 ; 58.8 \%$ ) of the participants mentioned the use of the following accessories to protect themselves from the sun: parasol/ umbrella ( $\mathrm{n}=58 ; 34.0 \%)$; hat $(\mathrm{n}=56 ; 33.0 \%)$; cap $(\mathrm{n}=38 ; 22.4 \%)$; sunglasses $(\mathrm{n}=10 ; 5.9 \%)$ and long- sleeved shirts ( $\mathrm{n}=8 ; 4.7 \%)$. While showering, 240 $(96.0 \%)$ of the participants used perfumed soap in bar form $(\mathrm{n}=242 ; 96.8 \%)$ with some coloration $(\mathrm{n}=235 ; 94.0 \%)$.

Of the 250 participants, 178 (71.2\%) had never been to see a dermatologist.

\section{DISCUSSION}

In the present study, only 23 ( $9.4 \%$ ) of the 250 elderly participants claimed to use sunscreen on a daily basis and only 194 (77.6\%) considered its use important. This result is in line with a recent study that reported the low use of sunscreen among the elderly population $(40.0 \%){ }^{15}$

The frequency and manner in which sunscreen is applied are essential to its effectivity, measured by the correct quantity and periodic reapplications. ${ }^{8,9}$ Most of the participants in the present study $(\mathrm{n}=223$; $89.3 \%$ ) stated that they did not use sunscreen on days when the sun was not visible. This finding is 
concerning and is consistent with an earlier study, which explained the errors associated with the use of sunscreen and the low levels of sunscreen reapplication $(33.0 \%){ }^{15}$

More than half ( $\mathrm{n}=147 ; 58.8 \%$ ) of the participants in the present study used some form of accessory for sun protection. The American Association of Dermatology (AAD) recommends the use of these accessories to minimize exposure to solar radiation. In addition, the use of darkcolored clothes with rigid, tightly-woven, thick fibers are also recommended as they provide greater protection against UV rays. ${ }^{16,17}$

These accessories are also useful in that they protect the scalp, the pinna portion of the outer ear, the eyes, the forehead and the neck, while also shading the face, nose and chin. The effectiveness of the protection provided by the use of a hat or cap is directly proportional to its size and the material it is made from..$^{15,16}$

Concerning body hygiene, 196 (78.4\%) of the participants of the present study said that they took warm showers, which is similar to the results of earlier studies that recommended using warm water for bathing. However, 5.4\% of the participants used hot water, which dries the skin and removes its natural oils..$^{17,18}$

Very few studies have been published on the ideal water temperature for elderly people when bathing/showering. Only the subjective terms hot, warm and cold have been used. For elderly skin, the water temperature should be warm or cold. ${ }^{18}$ Studies of the ideal temperature of bathwater for newborns recommend temperatures of between $34^{\circ}$ and $36^{\circ}$, as this is close to the temperature of the human body. ${ }^{19}$

Another factor that may affect the health of the skin is how it is cleaned while bathing. The quality of the soap (neutrality, type of application/ rinsing, perfumed or not) can affect the health of the skin. Scrubbing the skin with pads or brushes promotes the excessive removal of resident microbiota (endogenous), thereby exposing the skin to aggressions from exogenous microorganisms. ${ }^{19}$ The elderly should not use pads/brushes on their skin, as senility makes the skin more delicate and fragile, reducing the dermal papillae that promote the epidermis-dermis bond. Therefore, scrubbing the skin is contraindicated in order to avoid separating these skin layers, which often leads to lesions and bleeding. ${ }^{20,21,22}$

Concerning the $\mathrm{pH}$ of soaps/shower gels, the repeated use of these products can alter the $\mathrm{pH}$ of the cutaneous surface. A previous study ${ }^{20}$ analyzed the $\mathrm{pH}$ of 42 soaps destined for adult use on the Brazilian market, including those in bar and gel form. Most of the soaps in bars exhibited a $\mathrm{pH}$ of between 9 and 10 while the $\mathrm{pH}$ of the gels was less than 8 . Earlier studies ${ }^{20}$ recommended the use of soaps with an acidic $\mathrm{pH}$. These products do not have such a strong effect on the cutaneous microbiota and exhibit less deleterious effects as they are closer to the physiological $\mathrm{pH}$ (between 4.2 and 5.9, depending on the area of the body measured).

In the present study, most of the elderly individuals performed unsuitable skincare practices, particularly in relation to the use of perfumed soaps ( $\mathrm{n}=240 ; 96.0 \%$ ), bars of soap $(\mathrm{n}=242 ; 96.8 \%)$ and soap with some coloration in its appearance ( $\mathrm{n}=235 ; 94.0 \%)$. In addition, 153 $(61.2 \%)$ used a loofah to scrub their skin. Soap in bar form is more likely to dehydrate the skin and favors the accumulation of microorganisms in areas with cracks. Bath towels can also damage the skin's natural barrier through friction and damage caused by coarse fibers. The use of skin cleansers is recommended, as many of them do not require rinsing. ${ }^{21,22,23}$

With increasing age comes a decrease in cutaneous circulatory flow, as well as sclerosis of the major vessels, which contributes to the greater intensity of inflammatory reactions and the lower clearance of the endogenous and exogenous substances deposited in the dermis. This includes topically active drugs, which can have an effect 
with a lower number of daily applications. This should also be considered when analyzing the effects of other types of contact with the skin of elderly individuals. ${ }^{21}$

Skin hydration occurs naturally through the action of components in the sebaceous glands and the effect of the sweat glands in corneal layers, which form the hydrolipidic mantle. ${ }^{22}$ The cutaneous hydration of the surface can occur through occlusion or moistening (hydrophilic effect). In the former, the evaporation of water is reduced. In other words, lipid substances or emollients form a film on the surface of the skin, known as vegetable oil-based emulsions. The latter involves humectants (hydrophilic) and as such, the daily application of creams or liquid Vaseline is more favorable for this process. ${ }^{21,22}$ In the present study, the use of body moisturizer was cited by $139(55.6 \%)$ of the elderly participants, although only $77(30.8 \%)$ followed the relevant instructions.

Notably, water from the corneal extract can be endogenous and exogenous. The former comes from the ingestion of liquids, which are later sent to the dermis and the cutaneous surface. The latter is adsorbed from the environment, depending on the relative humidity of the air. Thus, the exogenous hydration of people who live in a dry climate represents a greater risk. ${ }^{23}$

In the present study, 129 elderly individuals stated that they ingested approximately one liter of water per day. However, the recommended quantity is a minimum of two liters and a maximum of two and a half liters. ${ }^{21}$ Only 121 (48.4\%) participants consumed two liters or more per day. The correct ingestion of water on a daily basis is imperative, given that it minimizes the damaging effects of the natural dehydration caused by senescence.

Another concerning factor is that a very small section of the interviewees $(\mathrm{n}=22 ; 8.8 \%)$ had been to see a dermatologist. Clinical diagnoses are an effective method of identifying certain pathologies. They are also sensitive, straightforward, practical and non-invasive. Nevertheless, the access to such professionals may not be easy for individuals relying on the Sistema Único de Saúde (Unified Health System). ${ }^{22,23,24}$

In Brazil, skin cancer is the most common of all types of cancer, corresponding to approximately $25.0 \%{ }^{25}$ of all tumors diagnosed across all geographic regions of the country in 2013. Natural ultraviolet radiation (from the sun) is the main etiological agent of this disease..$^{25}$

Skin cancer can be classified as melanoma and non-melanoma. The former is the most common of all types of malignant tumors recorded in the country, with high cure rates if detected early. Its incidence is also more common among Caucasian people under 40 years who do not adhere to photoprotective strategies. The latter type represents only $4.0 \%$ of malignant skin neoplasia, although it is more serious due to the high possibility of metastasis. An early diagnosis is advantageous to the prognosis in both types of diagnosis. ${ }^{25,26}$

According to the Sociedade Brasileira de Dermatologia (Brazilian Dermatology Society), certain foods, such as vegetables, fruit, fish and lean meats, improve the vitality of the skin and the functioning of the body. These foods help the body to prevent the formation of free radicals, which are strongly correlated with the acceleration of the aging process. ${ }^{18}$

The unsatisfactory results of the present study in terms of the practices of skincare are directly correlated with the culture of health practices and knowledge, and relationships with health education, which are imbued in each person. ${ }^{27}$ Thus, upon determining that the care product can be shared among the population, a clear dialogic process permeates this situation, in terms of a meeting between knowledge, sense and scientific and technical expertise.

Therefore, strategies that consider cultural standards to ensure their effectiveness and to maintain the health and wellbeing of the elderly population must be created. ${ }^{27}$ Appropriate levels 
of exposure to the sun could be one such strategy. The skin should preferably only be exposed to the sun before ten in the morning and after four in the afternoon, for a period of ten to 20 minutes. This optimizes the synthesis of vitamin $\mathrm{D}$, which is lower in the elderly for a number of reasons: less exposure to the sun; a reduced capacity to produce vitamin D; inappropriate nourishment; decreased absorption in the gastrointestinal tract; impaired kidney function; and the use of medicines that affect the absorption/metabolization of vitamin $\mathrm{D}$, which is essential for the maintenance of bone tissue and the immune system. This vitamin has been used in the treatment of autoimmune diseases, such as rheumatoid arthritis and multiple sclerosis. In the process of cellular differentiation, a lack of vitamin $\mathrm{D}$ favors 17 different types of cancer. ${ }^{28}$

Considering that the greatest source of vitamin $\mathrm{D}$ is exposure to the sun, the Recommended Dietary Allowance (RDA) suggests a number of strategies to reduce this problem for the elderly. One such strategy is the daily ingestion of 400 IU for those aged between 50 and 70 years and $600 \mathrm{IU}$ for those over 70 years. This corresponds to 20 minutes of exposure per day on $5 \%$ of the surface of the body. Vitamin D can also be found in certain foods (mushrooms and fish from cold waters), although these are not commonly found on menus in Brazil. ${ }^{28}$

Certain precautions should be taken with the skin of elderly individuals, including restricting the use of soaps/gels or detergents, avoiding the use of antiseptic soap, choosing neutral soap, avoiding exposure to the sun between 10am and $4 \mathrm{pm}$, using accessories to protect the skin from UV rays, using sunscreen, avoiding the use of pads/brushes when washing, ingesting between two and two and a half liters of water per day and maintaining a balanced diet. ${ }^{19,20,21,23}$

It is known that most skin cancers are related to exposure to the sun, particularly between the hours of 10 in the morning and four in the afternoon.
During this time, UVB radiation is more intense and the relevant precautions should be taken, such as covering exposed areas of the skin with appropriate clothing, among others. Therefore, exposing the arms and legs to the sun's rays before $10 \mathrm{am}$ provides preventive health benefits related to the level of vitamin D in the human body. ${ }^{29}$

In the present study, while it was found that many elderly individuals recognize the health benefits of using sunscreen, it was not possible to identify the reasons why they do not use it correctly. Further studies are required to clarify this issue.

\section{CONCLUSION}

Our skin protects us and is indispensable to our health. In the present study, it was found that, due to a lack of practice or knowledge, elderly individuals neglect simple self-care tasks, such as using sunscreen on a daily basis and on cloudy days, despite the fact that they are aware of its importance. Many elderly individuals also do not ingest enough liquids to keep their skin hydrated.

Taking baths/showers with warm water and using body moisturizers are recommended by health agencies, although they should not be used every day. The use of unsuitable products, such as loofahs, soap in bar form, colored soap and perfumed soap is contraindicated. The quantity of water ingested by the interviewees was not in accordance with the recommended levels.

Very few of the participants had ever visited a dermatologist, despite the fact that the majority were Caucasian and had a history of jobs in which they were exposed to the sun on a daily basis.

Given the results of the present study, further research should be conducted to clarify certain factors related to inadequate skincare and to facilitate the creation of educational measures for the population as a whole, regardless of age, in order to prevent pathological skin aging. 


\section{REFERENCES}

1. Baroni ERV, Simões MLPB, Auersvald A, Auersvald LA, Netto MRM, Ortolan MCAB. Influence of aging on the quality of the skin of white women: the role of collagen. Acta Cir Bras [Internet] 2012 [acesso em 29 jul. 2014];27(10):736-40. Disponível em: http://www.scielo.br/scielo.php?pid=S010286502012001000012\&script=sci_arttext

2. Resende DM, Bachion MM, Araújo LAO. Integridade da pele prejudicada em idosos: estudo de ocorrência numa comunidade atendida pelo Programa Saúde da Família. Acta Paul Enferm [Internet] 2006 [acesso em 10 jul. 2014];19(2):168-73. Disponível em: http:// www.scielo.br/scielo.php?script=sci_arttext\&pid $=$ S0103-21002006000200008

3. Dinato SLM, Matos ODM, Alverto MS, Marques BW. Prevalência de dermatoses em idosos residentes em instituição de longa permanência. Rev Assoc Med Bras [Internet] 2008 [acesso em 24 jul. 2014];54(6):543-7. Disponível em: http://www.scielo. br/pdf/ramb/v54n6/v54n6a20.pdf

4. Diffey B. Sunscreens: expectation and realizations. Photodermatol Photoimmunol Photomed 2009;25: 233-6.

5. Gomes FSL, Antonini MRB, Penido FM, Rotelli HT, Velásquez GM. Fatores associados à úlcera por pressão em pacientes internados nos Centros de Terapia Intensiva de Adultos. Rev Esc Enferm USP [Internet] 2010 [acesso em 25 jul. 2014];44(4):1070-6. Disponível em: http://www.scielo.br/scielo.php?pid=S008062342010000400031\&script=sci_arttext

6. Freitas LDO, Waldman BF. O Processo de envelhecimento da pele do Idoso: diagnósticos e intervenções de enfermagem. Estud Interdiscip Envelhec 2011;16:485-97.

7. Sgarbi FC, Carmo ED, Rosa LEB. Radiação ultravioleta e carcinogênese. Rev. Ciênc Méd (Campinas) 2007;16(4-6):245-50.

8. Montagner S, Costa A. Bases biomoleculares do fotoenvelhecimento. An Bras Dermatol 2009;84(3):263-9.

9. Sergio S, Rei VMS. Fator de proteção solar: significado e controvérsias. An Bras Dermatol 2011;86(3):507-15.

10. Castro MR, Figueiredo NMA. O estado da arte sobre cuidado ao idoso: diagnóstico da produção científica em enfermagem. Physis [Internet] 2009 [acesso em 2 mar. 2012];19(3):743-59. Disponível em: http://www.scielo.br/scielo.php?pid=S010373312009000300011\&script=sci_arttext
11. Oriá RB, Ferreira FVA, Santana ENS, Fernandes MR, Brito GAC. Estudo das alterações relacionadas com a idade na pele humana, utilizando métodos de histo-morfometria e autofluorescência. An Bras Dermatol 2003;78(4):425-34.

12. Instituto Brasileiro de Geografia Estatística [Internet]. Cidades Arcos, MG: IBGE; 2012 [ acesso em 10 mar. 2012]. Disponível em: http://www.ibge.gov.br/home

13. Brasil. Resolução no 196. Diretrizes e normas regulamentadoras sobre pesquisa envolvendo seres humanos. CNS .1996.

14. Classificação Brasileira de Ocupações: CBO - 2010 . 3a ed. vol. 1. Brasília, DF: MTE: SPPE; 2010.

15. Balogh TS, Velasco MVR, Pedriali CA, Kaneko TM, Baby AR. Ultraviolet radiation protection: current available resources in photoprotection. An Bras Dermatol [Internet] 2011 [acesso em 25 jul. 2012];86(4):732-42. Disponível em: http://www. scielo.br/scielo.php?script $=$ sci_arttext\&pid $=$ S036505962011000400016\&lng=en\&nrm=iso\&tlng=en

16. Baron ED, Kirkland EB, Domingo DS. Advances in photoprotection. Dermatol Nurs 2008;20:265-72.

17. Conceição LFS. Saúde do idoso: orientações ao cuidador do idoso acamado. Rev Med Minas Gerais 2010;20(1):81-9.

18. Portal da Sociedade Brasileira de Dermatologia [Internet]. Rio de Janeiro: SBD; 2014. Cuidados com a pele no Inverno; 2014 [acesso em 29 jul. 2014]; [aproximadamente 2 telas]. Disponível em: http://www.sbd.org.br/cuidados/cuidados-com-apele-no-inverno

19. Blume-Peytavi U, Cork MJ, Faergemann J, Szczapa J, Vanaclocha F, Gelmetti C.Bathing and cleansing in newborns from day 1 to first year of life: recommendations from a European round table meeting. J Eur Acad Dermatol Venereol 2009;23(7):751-9.

20. Volochtchuk OM,Fujita EMi, Fadel APC, Auada MPA, Almeida T, Marinoni LPeide Parolin. Variações do pH dos sabonetes e indicações para sua utilização na pele normal e na pele doente. An Bras Dermatol 2000;75(6):697-703.

21. Domansky RC, Borges EL. Manual para prevenção de lesões de pele: recomendações baseadas em evidência. $2^{\mathrm{a}}$ ed. Rio de Janeiro: Rubio; 2014.

22. Sampaio SAP, Castro RM, Rivitti E. Dermatologia Básica. 9a ed. São Paulo: Artes Médicas; 2007. 
23. Gomes RK, Damazio MG. Cosmetologia: descomplicando os princípios ativos. $3^{\mathrm{a}}$ ed. São Paulo: Livraria Médica Paulista; 2009.

24. Watkins P. Using emollients to restore and maintain skin integrity. Nurs Stand 2008;22(41):51-7.

25. Brasil. Instituto Nacional do Câncer. Como prevenir o câncer de pele [Internet]. Rio de Janeiro: INCA; 2014 [acesso em 6 dez. 2014]. Disponível em: http:// www.inca.gov.br/resultado.asp

26. Antônio JR, Soubhia RMC, D’Avila SCGP, Caldas AC, Trídico LA, Alves FT.Correlation between dermoscopic and histopathological diagnoses of atypical nevi in a dermatology outpatient clinic of the Medical School of São José do Rio Preto, SP, Brazil. An Bras Dermatol 2013;88(2):199-203.
27. Teixeira MLO, Ferreira MA. Cuidado compartilhado: uma perspectiva de cuidar do idoso fundamentada na educação em saúde. Texto contexto Enferm 2009;18(4):750-8.

28. Saraiva GL, Cendoroglo MS, Ramos LR, Araújo LMQ, Vieira JGH, Maeda SS, et al. Prevalência da deficiência, insuficiência de Vitamina D e Hiperparatiroidismo Secundário em idosos institucionalizados e moradores na Comunidade da Cidade de São Paulo, Brasil. 437 Arq Bras Endocrinol Metab 2007;51(3):437-42.

29. Sociedade Brasileira de Dermatologia. Sobre o Câncer de Pele. Rio de Janeiro: SBD; 2015 [acesso em 5 out. 20145]. Disponível em: http://www.sbd.org.br/ informacoes/sobre-o-cancer-da-pele/como-preveniro-cancer-da-pele/

Received: December 15, 2014

Revised: August 08, 2015

Accepted: September 25, 2015 